\title{
Evaluating the benefits of mixed plantain/chicory/clover pastures in a Hawke's Bay sheep breeding and finishing farm
}

\author{
Jim SPALL ${ }^{1 *}$, Graeme I. OGLE ${ }^{2}$ and Paul D. MUIR ${ }^{3}$ \\ ${ }^{1} 2289$ Kereru Rd, Hastings, New Zealand \\ ${ }^{2}$ Ogle Consulting, 585 Bruntwood Road, RD1, Cambridge, New Zealand \\ ${ }^{2}$ On-Farm Research, PO Box 1142, Hastings, New Zealand \\ *jimspal115@outlook.com
}

\begin{abstract}
Farming in the inland Hawke's Bay, New Zealand with traditional pasture is limited by pasture quality in summer and early autumn. Low lamb growth rates in spring/summer pushes lamb finishing into the late summer and early autumn when feed demand competes with sheep mating and compromises pasture cover entering winter. We discuss our process for investigating and adopting high legume herb-based pastures that thrive within the constraints of our soils. This process involved learning from other farms and trials, smallscale on-farm trials and farm-system modelling. We gain considerable confidence from observing plantain, chicory and clover pastures within a learning group run by Massey University. Our on-farm trial measured by On-Farm Research showed favourable forage production $(+20 \%$ greater than ryegrass-clover pastures for spring, autumn and winter) and longevity (4-6 grazing seasons). From this we modelled our farm using Farmax software. Farmax calculated an historically poor performance in February, March and April from ewes $(-65,-45,-15 \mathrm{~g} /$ day respectively) and lambs $(55,0,35 \mathrm{~g} /$ day respectively). Based on six key assumptions, we have calculated the profitability of herb-based pastures. These are compared with the performance we are currently achieving on herb-based pastures. For each value we are achieving better than assumed, i.e. ewe weaning weight 64.0 versus $62 \mathrm{~kg}$, lamb weaning weight 33.0 versus $31.3 \mathrm{~kg}$, ewe lamb growth rate 132 versus $100 \mathrm{~g} /$ day, male lamb growth rate 253 versus 235 grams/day and ewe hogget scanning percentage 144 versus 130 .
\end{abstract}

Keywords: Plantain, chicory, herb-based, animal performance, forage productivity, modelling

\section{Introduction}

Our farm, Poporangi, is constrained by low livestock performance in summer and early autumn. This results in lamb finishing competing with ewe mating and a system highly vulnerable to poor autumns. We were aware of how farmers in other dry regions (Avery et al. 2008) have adopted a lucerne grazing system and reduced the dependence on late season feed. We could see legume-based pastures would greatly benefit our farm but lucerne does not thrive on our soils due to an impervious pan. Therefore, we investigated plantain, chicory and clover pasture mixtures being trialled by Massey University. Our paper reports our method of investigating and adopting these pastures and our early results.

\section{Farm Description}

\section{Climate, contour, soils and vegetation}

Poporangi is a sheep and cattle property located at Kereru $44 \mathrm{~km}$ west of Hastings in the Hawke's Bay region of the North Island, New Zealand. Our average rainfall is higher than for dryland properties that are closer to the coast $(1044 \mathrm{~mm}$ and $700-800 \mathrm{~mm}$ respectively). Typically, we have low growth rates in summer when evapotranspiration is higher than rainfall. Our rainfall is highly variable (708 $\mathrm{mm}$ to $1270 \mathrm{~mm}$ ) and drought is a regular occurrence.

The 477-ha property comprises 374 ha of flat to rolling country and 103 ha of gorges of which 18 ha is at the start of a second forestry rotation and 85 ha is in regenerating bush. The two main soil types, Poporangi sandy loam and Mangatahi sandy loam, are characterised by low natural phosphate levels, medium to high phosphate retention and a hard duripan at 35-40 $\mathrm{cm}$ causing impeded drainage. The property is well developed with over 100 paddocks, all reticulated, and an extensive road and lane network. Water comes either from a spring or dam sources, all fenced and the latter protected with plantings of native species.

Priority has been to lift phosphate levels, which now average an Olsen $\mathrm{P}$ of 26 , implement a drainage programme, and to protect the soils from pugging damage during wet periods. The duripan restricts the number of older cattle that can be run through winter and greatly limits the use of lucerne.

Of the 374 effective hectares, 206 ha have been renewed over the last 26 years with 132 ha in ryegrass or fescue-based pastures, 5.5 ha is in lucerne and, as of this spring, 69 ha of the farm is in a herb mix of plantain, chicory and clover. Over the last two seasons, coated white clover seed has been added to the annual fertiliser to increase legume content. 


\section{Livestock}

The property runs three enterprises: breeding and finishing sheep; bull beef; and breeding cows. The sheep are a highlander breed comprising 1800 ewes and 600 hoggets producing replacement and finishing lambs. Lambing (lambs docked/ewes tupped) has averaged $144 \%$ over the last 5 years while approximately half the hoggets are also mated. The bull-beef policy buys bulls as calves in spring then tops up in February to winter 200 rising 1-year bulls. Sixty percent of these are finished through the following summer and autumn with the remainder finished the following winter and spring. A small herd of 30 breeding cows are also run and provide a means of cleaning up pasture.

\section{System constraints}

Our pastures dry up in summer so stock performance declines through mid to late summer and early autumn. Our unimproved pastures are typical of east-coast hill country (ryegrass, browntop, sweet vernal and low productivity clovers) which have a low clover content as the dry months set in. Low lamb growth rates push lamb finishing into autumn and early winter where feed demand competes with ewe tupping and beef performance. This also means we are vulnerable to dry autumns when lambs cannot be finished and are sold store on a soft market and pasture cover entering winter is sub-optimal.

\section{System improvement - Methods}

Our soils are not suited to lucerne so we were keen to investigate other pastures with a high legume content. Gaining an understanding of our alternatives and building the confidence to make the transition has so far involved three steps:

- Learning from other farms. In 2010, we became aware of Massey University research on the use of different plantain, chicory and clover mixes (hereafter referred to as herb-based pasture) to boost lamb growth rates. The two mixes were chicory (Chicorium intybus)/plantain (Plantago major)/white and red clover (Trifolium repens, Trifolium pratense) and plantain/clover. On enquiry, I was invited to join a farmer learning group. Over a three-year period (June 2011 to June 2014) we visited farmlet trials and commercial farms quarterly.

- Small-scale on-farm trial. In 2011 we planted 7 ha of herb-based pasture. To assess the performance, we joined a project with On Farm Research, a locally based research company, which measured yields of herb-based pastures on six East Coast farms (Muir et al. 2019). On Poporangi, we compared the herb-based pasture and an area sown in ryegrass-clover (cultivar of ryegrass One-50) in March 2011. Measurements started in late summer 2013.

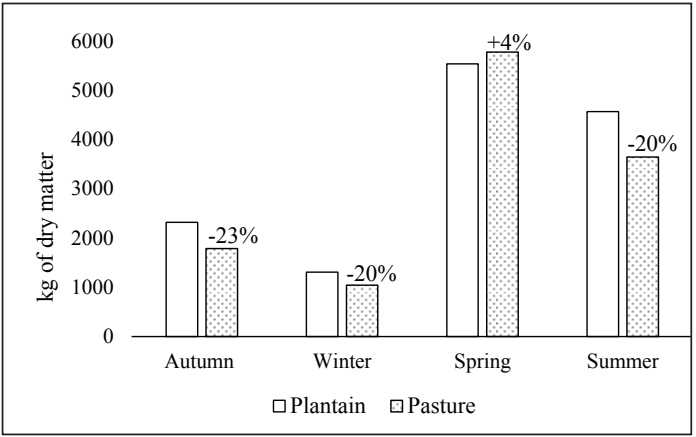

Figure 1 Seasonal growth rates for the herb-based pasture compared with a ryegrass pasture measured from autumn 2013 to winter 2016.

- Farm system modelling. In mid-2016, we had our system analysed as part of an extension project funded by the Red Meat Profit Partnership and Progressive Meats. This analysis started with analysing our livestock performance for the five years from 2011 to 2015 using the Farmax modelling software (Bryant et al. 2010). Opportunities to improve productivity and profit were considered as well as the optimal area of herb-based pastures.

\section{System improvement - Results}

Being able to learn from other farmers gave knowledge and confidence to start growing and using herb-based pastures. The measurement of production by On Farm Research further increased our confidence. The herbbased pasture was measured from autumn 2013 when it was two years old (sown November 2011) to the winter of 2016 when it was five years old. Over this period, it grew approximately $20 \%$ more dry matter for each season except spring when it was similar (Figure 1). We had expected the annual production from herb-based pastures to drop markedly from the third year of grazing but the last year of measurement (2015/2016) showed the annual production was just $4 \%$ less than the ryegrass $(10,420 \mathrm{~kg}$ versus $10,910 \mathrm{~kg}$ respectively).

The farm was modelled using Farmax software to quantify the financial gains obtained from the expansion of the herb-based pastures, and was based on key assumptions for stock performance and pasture longevity. To initiate the model, we used our five-year measurements of stock weights to calculate bodyweight (free of wool and conceptus) profiles. The results showed that, on average, ewes lost significant body weight for February, March and April $(65,45$ and $15 \mathrm{~g}$ /day loss respectively), while the lambs grew modestly (55, 0 and $35 \mathrm{~g} /$ day; Table 1$)$. It was not possible to compare liveweight gains on the herb area for long periods (due to the small area making grazing 
durations short) but, for the brief periods measured, we estimated lambs had grown above $200 \mathrm{~g}$ /day during summer and autumn.

This paper does not undertake to report on the details of the Farmax modelling process. However, results from the model enabled us to determine if the herb pastures added significantly to farm profit as long as the key assumptions used (Table 2) held true. Maximum profit was reached when $50 \%$ of our farm area was in herb-based pastures. At this level, all finishing lambs and replacement hoggets could be raised on herb-based pastures and all multiple ewes and two-tooth ewes could be lambed on herb-based pastures and carried through to weaning. As we have increased the area in herb-based pastures, we have been able to compare our actual performance with these assumptions. Our performance is currently better than we had assumed in all key areas.

\section{Longevity and management of herb-based pastures}

To date, we have had achieved 4 to 6 grazing seasons from herb pastures. We include chicory to reduce the risk of an insect or disease significantly affecting one component. Chicory is valued both for its high metabolisable energy and its performance under moisture stress. Over time, plantain becomes more dominant as reseeding occurs naturally.

Table 1 Calculation of maternal ewe and sale lamb body weight gains from 1) weighing ewes at weaning, mating and scanning 2) lamb weaning weight then calculation of sales weights modelled from carcass weights at slaughter.

\begin{tabular}{llc}
\hline & \multicolumn{2}{c}{ Grams of body weight gain/day } \\
Ewes & Sale lambs \\
\hline February & -65 & 55 \\
March & -45 & 0 \\
April & -15 & 35 \\
\hline
\end{tabular}

\section{Establishment and renewal}

Preparation normally starts with a rape crop (Brassica napus) in the preceding year. Drainage work is carried out prior to planting if required. Preparation normally involves discing, power harrowing, and drilling using an air seeder. The rape may be grazed by ewe lamb replacements but is primarily for flushing ewes. Italian ryegrass (Lolium multiflorum) is direct drilled into the stubble in April. The duripan may mean soil is waterlogged in winter and early spring so cultivation can occur only when soil conditions allow. Cultivation and drilling the herb-based pasture follows the same process as outlined above with $200 \mathrm{~kg} / \mathrm{ha}$ of NPK fertiliser. A spray for the control of redroot (Amaranthus powelli) and other annual weeds is normally applied soon after germination. Rotational grazing with finishing lambs commences once the chicory plants have 7 leaves. Renewal starts with spraying off in autumn followed by direct drilling a short rotation ryegrass with a return to herb pasture 9 to 21 months later.

\section{Grazing Management}

Grazing is spelled over winter to allow the chicory taproot to recover. The first grazing is from mid-August with multiple lambing ewes. Rotational grazing is implemented as soon as possible targeting a pre-graze height of greater than $12 \mathrm{~cm}$ and a post-grazing height of $7 \mathrm{~cm}$. From weaning at the start of December, the herb pastures are largely used for lamb finishing with an initial stocking rate of around 30 lambs per hectare. As the area has expanded, it has become possible for some of the replacement lambs to also have herb pastures incorporated into their rotation. The herb pastures are also used for tupping of the hoggets in May. If possible, grazing ceases in early June.

\section{Weed Control}

The open leafy sward structure is ideal for clover but unfortunately also perfect for invasive weeds. Grass control is straightforward with the application of an

Table 2 Comparison between the historical (five-year Farmax analysis) livestock performance, the Farmax modelling of the optimum policy and actual data collected for the 2018-2019 year; $\mathrm{nc}=$ not calculated from Farmax modelling. Figures in brackets are for livestock run during the 2018-2019 year on ryegrass-based pasture.

\begin{tabular}{lccc}
\hline Factor & Historical model & Key assumptions & Measured \\
\hline Ewe stocking rate (SU/ha) & $\mathrm{nc}$ & $\mathrm{nc}$ & $10.4(9.7)$ \\
Ewe weaning weight (kg) & 55.0 & 62.0 & $64.0(55.0)$ \\
Lamb weaning weight (kg) & 27.6 & 31.3 & $33.0(27.0)$ \\
Ewe lamb growth rate Feb to April (g/day) & 15 & 100 & 132 \\
Male lamb growth rate Feb to April (g/day) & 135 & 235 & 252 \\
Ewe lamb scanning \% & 109 & 130 & 144 \\
Pasture longevity (seasons grazed) & $\mathrm{nc}$ & 4 & $4-6$ \\
\hline
\end{tabular}


appropriate herbicide (clethodim) in early spring. Including chicory in the sward reduces chemical control options for other weeds, of which Californian thistle (Cirsium arvense), nodding thistle (Carduus nutans), Australian sedge (Carex longebrachiata) and rushes are the most problematic. Both weed wiping and topping are regularly used to maintain a measure of control.

\section{Fertiliser}

The herb pastures receive an annual application of 250 $\mathrm{kg} / \mathrm{ha}$ of NPKS $(21,30,25,25)$ in March and $80 \mathrm{~kg} / \mathrm{ha}$ of urea in early August.

\section{Conclusions}

Herb-based pastures now make up around $15 \%$ of our farm. The confidence to make this change has followed a process of observing farms and experimental farmlets, on-farm production measurements, then farm modelling to explore the optimal area and financial returns. This modelling shows the optimal area is likely to be $50 \%$ of the farm. At this point, the higher quality from herbbased pastures will drive sheep production early in the season reducing reliance on stock performance in

\section{Table 3}

Costs for establishing and maintaining plantain based on expenditure for the 2018-2019 year. All activities are carried by contractors except $\left.{ }^{*}\right)$ which is based on estimates of staff time and materials.

\begin{tabular}{lc}
\hline Establishment costs & \$/ha \\
\hline Spray off & 83 \\
Cultivation and drilling & 390 \\
Fertiliser & 156 \\
Seed & 416 \\
\hline Total establishment costs & 1045 \\
\hline Annual costs & $\$ / h a$ \\
\hline Grass spray & 111 \\
Urea & 70 \\
Weed control & $100^{*}$ \\
Annual fertiliser & 196 \\
\hline Total annual costs & $\mathbf{4 7 7}$ \\
\hline
\end{tabular}

summer and early autumn. However, these outcomes depend on key assumptions for stock and pasture performance. To date, our on-farm pasture trials and measurements of stock performance indicate we are achieving targets in all key areas. Further developments in weed control could lower annual maintenance costs (Table 3), improve productivity and extend the life of our herb-based pastures.

Our mix of plantain, chicory and clover in our herbbased pasture grows well on our property with its climate, topography, and soil types (limited drainage with a duripan layer). For other properties with different resource combinations the key is in finding the species that thrive and the management required to realise the benefits.

\section{ACKNOWLEDGEMENTS}

Data collection was carried out with funding from MPI's Sustainable Farming Fund (Project 11/104 and 401457; Beef + Lamb NZ and the Hawke's Bay Regional Council) and the MBIE Hill Country Regeneration. Programme BLNZT1701 with funding from MIBIE, Beef + Lamb NZ, Seed Force and PGGW contributed to the publication of this work. The modelling within this project was carried out with funding from the Red Meat Profit Partnership and Progressive Meats.

\section{REFERENCES}

Avery D, Avery F, Ogle GI, Wills BJ, Moot DJ. 2008. Adapting farm systems to a drier future. Proceedings of the New Zealand Grassland Association 70: 1318.

Bryant JR, Ogle G, Marshall PR, Glassy CB, Lancaster JAS, Garcia SC, Holmes CW. 2010. Description and evaluation of the Farmax Dairy Pro decision support tool. New Zealand Journal of Agricultural Research, 53: $13-28$.

Muir PD, Thomson BC, Smith NB, Ward KR, MacGillivray L, Macfarlane MJ. 2019. The performance and profitability of plantain/clover pasture mixtures in East Coast farming systems. Journal of New Zealand Grasslands 81: 81-86.

Sewell AM, Gray DI, Blair HT, Kemp PD, Kenyon PR, Morris ST, Wood BA. 2014. Hatching new ideas about herb pastures, Learning together in a community of New Zealand farmers and agricultural scientists. Agricultural Systems 125: 63-73. 